\title{
Single-and Dual-species Biofilm Formation of Pseudomonas aeruginosa and Staphylococcus sciuri on Catering Kitchen Surfaces in Health Establishments
}

\author{
Sağlık Kuruluşlarında Mutfak Yüzeylerinde Pseudomonas aeruginosa ve Staphylococcus \\ sciuri'nin Tek ve Çift Tür Biyofilm Oluşumu
}

\author{
(1) Khaddouj AMZIL ${ }^{1}$, (1) Fatima HAMADI ${ }^{1}$, (1) Rachida MIMOUNI ${ }^{1}$, (1) Hassan LATRACHE ${ }^{2}$, (1) Aissa SAIDI ${ }^{1}$, (1) Khadija AZELMAD ${ }^{1}$, \\ (1) Jaouad ABOU OUALID ${ }^{3}$, (1) Asma LAKTIB ${ }^{1}$, (1) Mariem ZANZAN ${ }^{1}$ \\ 1 Ibn Zohr University Faculty of Sciences, Laboratory of Microbial Biotechnology and Vegetal Protection, Morocco, North Africa \\ 2Sultan Moulay Slimane University Faculty of Sciences and Techniques, Laboratory of Bioprocess and Bio-interfaces, Morocco, North Africa \\ $3 / \mathrm{bn}$ Zohr University Faculty of Sciences, Laboratory of Aquatic System: Marine and Continental Environment, Morocco, North Africa
}

\section{Abstract}

Introduction: Biofilms formed by Pseudomonas aeruginosa and Staphylococcus sciurion the surfaces of food preparation tables present a significant risk to public health. This study aimed to investigate the adhesion and formation of single- and dual-species biofilms of $P$. aeruginosa and S. sciuri on granite and stainless steel surfaces.

Materials and Methods: Bacterial strains were identified by polymerase chain reaction and sequencing methods. The plate count method and epifluorescence microscopy (EP) were used to assess adhesion and biofilm formation.

Results: P. aeruginosa was more effective alone in adherence and biofilm formation than with S. sciuri. The EP dual-species biofilm analysis showed that biofilm cells heavily adhered to stainless steel 304 and granite, Rosa Porrino, whereas granite, Gris Pinhel, and stainless steel 316 provided less suitable growth matrices.

Conclusion: The quantity of extracellular polymeric substances affecting the appearance of bacterial cells was of greater importance on granite than on stainless steel. The surface type has an effect on adhesion and biofilm formation in dual and single cases of biofilm formation.

Keywords: Adhesion, biofilm, P. aeruginosa, S. sciuri

\section{Öz}

Giriş: Yemek hazırlama masalarının yüzeylerinde Pseudomonas aeruginosa ve Staphylococcus sciuri'nin oluşturduğu biyofilmler halk sağlığı için önemli bir risk oluşturmaktadır. Bu çalışma, P. aeruginosa ve S. sciuri'nin tek ve çift tür biyofilmlerinin granit ve paslanmaz çelik yüzeylere yapışmasını ve oluşumunu araştırmayı amaçlamıştır.

Gereç ve Yöntem: Bakteri suşları, polimeraz zincir reaksiyonu ve dizileme yöntemleri ile tanımlandı. Yapışma ve biyofilm oluşumunu değerlendirmek için plaka sayımı yöntemi ve epifloresan mikroskopisi (EP) kullanıldı.

Bulgular: P. aeruginosa tek başına yapışma (adezyon) ve biyofilm oluşumunda S. sciuriłe göre daha etkiliydi. Epifloresan mikroskopisi çift tür biyofilm analizi; biyofilm hücrelerinin paslanmaz çelik 304 ve Rosa Porrino granitine yoğun şekilde yapıştığını, oysa Gris Pinhel graniti ve paslanmaz çelik 316'nın daha az uygun büyüme matrisleri sağladığını gösterdi.

Cite this article as: Amzil K, Hamadi F, Mimouni R, Latrache H, Saidi A, Azelmad K, Abou Oualid J, Laktib A, Zanzan M. Single-and Dual-species Biofilm Formation of Pseudomonas aeruginosa and Staphylococcus sciuri on Catering Kitchen Surfaces in Health Establishments. Mediterr J Infect Microb Antimicrob. 2021;10:59. Mediterr J Infect Microb Antimicrob. 2021;10:59.

Address for Correspondence/Yazışma Adresi: Fatima Hamadi MD, Ibn Zohr University Faculty of Sciences,

Laboratory of Microbial Biotechnology and Vegetal Protection, Morocco, North Africa

E-mail: f.hamadi@uiz.ac.ma

Received/Geliş Tarihi: 06.12.2020 Accepted/Kabul Tarihi: 14.09.2021 ORCID ID: orcid.org/0000-0002-9740-1948

- ${ }^{\circ}$ Copyright 2021 by the Infectious Diseases and Clinical Microbiology Specialty Society of Turkey

Mediterranean Journal of Infection, Microbes and Antimicrobials published by Galenos Yayinevi. 
Sonuç: Bakteri hücrelerinin görünümünü etkileyen hücre dışı polimerik maddelerin miktarı granit üzerinde paslanmaz çelikten daha büyük önem taşıyordu. Yüzey tipi, ikili ve tek biyofilm oluşumu durumlarında yapışma ve biyofilm oluşumu üzerinde etkilidir.

Anahtar Kelimeler: Adezyon, biyofilm, P. aeruginosa, S. sciuri

\section{Introduction}

Staphylococcus sciuri is a dangerous human pathogen responsible for endocarditis, peritonitis, urinary tract infection, pelvic inflammatory disease, and wound infections ${ }^{[1]}$. It has been associated with infection outbreaks in hospitals ${ }^{[2]}$ and is known for its ability in adhesion, biofilm formation ${ }^{[3]}$, and resistance to antibiotics ${ }^{[4]}$. Pseudomonas aeruginosa is a human pathogen, which lives in soil, marshes, and coastal marine habitats, as well as on plant and animal tissues. P. aeruginosa can adhere to surfaces and engage in biofilm formation ${ }^{[5]}$.

Biofilm formation on surfaces has become a serious problem in industrial settings and domestic kitchens. Many studies have been carried out to broaden the understanding of this natural phenomenon and the processes involved. Biofilms are composed of bacterial cells and extracellular polymeric substances (EPSs), which include polysaccharides, proteins, nucleic acids, and lipids $^{[6]}$. This array provides a wide scope of protection for bacteria from disinfectants ${ }^{[7]}$. Moreover, biofilm formation is influenced by other factors, including physicochemical properties of bacterial surfaces and substrates ${ }^{[8]}$. In nature, a biofilm may be formed by several microorganisms, including bacteria. $P$. aeruginosa and $S$. sciuri engage in biofilm formation processes. Divya et al. ${ }^{[3]}$ reported that $S$. sciuri could produce biofilm even when exposed to stress factors. Meanwhile, $P$. aeruginosa shows an ease of adherence in its affinity to surfaces commonly found in catering kitchens, such as stainless steel ${ }^{[9]}$ and granite ${ }^{[5]}$.

This study aimed to clarify the effect of surface type, commonly found in catering and domestic kitchens, on single- and dualspecies complexes of bacterial adhesion and biofilm formation.

\section{Materials and Methods}

Isolation and Identification of Bacterial Strains

The bacterial strains used in the present study were $P$. aeruginosa and $S$. sciuri, which were isolated from catering surfaces in health establishments. $P$. aeruginosa was isolated from a stainless steel surface, whereas $S$. sciuri was isolated from porcelain and cultured in solid Luria-Bertani (stored at $4{ }^{\circ} \mathrm{C}$ until use). Both bacteria were isolated according to the standard, ISO 14698-1, and identified as described below.

The genomic DNA of each bacteria studied was extracted from pure cultures using the NucleoSpin kit (MACHEREY-NAGEL, Germany). For molecular detection, the primers (S-D-Bact-
0341-b-S-17, 5'CCTACGGGNGGCWGCAG-3' and S-D-Bact0785-a-A-21, 5'-GACTACHVGGGTATCTAATCC-3') that amplified the 464-bp fragment of the 16S rRNA gene, were used with a previously described protocol ${ }^{[10]}$. The polymerase chain reaction (PCR) products were excised from the gel, purified with the gel and PCR clean-up of the NucleoSpin kit, and submitted to a sequencing provider service (Bio Basic Inc., ON-Canada) for Sanger sequencing using primer sequences as for the PCR reaction.

Two sequences were submitted to the Genbank with accession numbers MN781137 for Staphylococcus sp. and MN781405 for Pseudomonas sp. The sequences obtained were analyzed using a basic local alignment search tool (BLAST) ${ }^{[11]}$ to identify sequence similarity. Phylogenetic analysis was carried out using the MEGA7 ${ }^{[12]}$ tool to ascertain the extent of homology. Bioinformatic analyses of the sequences identified MN781137 as S. sciuri and MN781405 as P. aeruginosa. The corresponding phylogenic relationship trees are shown in Figures 1 and 2.

\section{Bacterial Suspension Preparation}

Three independent culture replicates of each bacterium were grown at $37{ }^{\circ} \mathrm{C}$ for $24 \mathrm{~h}$ on solid Luria-Bertani. The medium was composed of the following: 10-g tryptone, 5-g yeast extract, 10-g NaCl, 15-g agar, and 1-L distilled water. After $24 \mathrm{~h}$ of incubation, bacterial cells were scraped off the agar plates and harvested by centrifugation at $8400 \times g$ for $15 \mathrm{~min}$. Cell pellets were resuspended in $\mathrm{KNO}_{3}(0.1 \mathrm{M})$ and adjusted to an optical density of 0.7-0.8 [corresponding to $10^{8}$ colony-forming units (CFU) $/ \mathrm{mL}$ ] using a spectrophotometer at $600 \mathrm{~nm}$.

\section{Surfaces Preparation}

Surfaces were cut into small sections; the size of Rosa Porrino and Gris Pinhel granites was $2 \times 2 \mathrm{~cm}$, with a thickness of $5 \mathrm{~mm} \pm 1$ $\mathrm{mm}$, whereas the size of the stainless steel was $1 \times 1 \mathrm{~cm}$. These surfaces were sterilized via immersion in absolute ethanol (99.9\%) for 15 min. Surfaces were rinsed three times with distilled water and autoclaved at $121^{\circ} \mathrm{C}$ for $20 \mathrm{~min}^{[13,14]}$.

\section{Bacterial Adhesion Test}

The sterilized surfaces were immersed in the Petri dishes containing $15 \mathrm{ml}$ of bacterial suspension $\left(10^{8} \mathrm{CFU} / \mathrm{mL}\right)$ for $3 \mathrm{~h}$ at $25^{\circ} \mathrm{C}$. The coupons were then rinsed three times with sterilized distilled water to remove the non-adhering bacteria. The coupons were immersed in a test tube containing physiological water ( $\mathrm{NaCl}: 9 \mathrm{~g} . \mathrm{l}-1)$. Bacterial cells were detached from the inert support using a sonication bath at $35 \mathrm{kHz}$ (ultrasonic, Germany) 
for $10 \mathrm{~min}$. The CFUs were counted using a serial dilution of the bacterial suspension obtained after sonication. Counts were determined on nutrient agar plates after incubation for $24 \mathrm{~h}$ at $37^{\circ} \mathrm{C}$ using the plate count method (PCM). Each experiment was performed in triplicate. The results were expressed in $\mathrm{CFU} / \mathrm{cm}^{2}$.

\section{Biofilm Formation Test}

As for the adhesion test, sterilized surfaces were immersed in Petri dishes containing $15 \mathrm{~mL}$ bacterial suspension $\left(10^{8} \mathrm{CFU} / \mathrm{ml}\right)$ for $3 \mathrm{~h}$ at $25^{\circ} \mathrm{C}$. The surfaces were rinsed three times with sterile distilled water to remove the non-attached bacteria. Surfaces were placed in Luria-Bertani broth and incubated at $25{ }^{\circ} \mathrm{C}$ for $24 \mathrm{~h}$. Three replicates were carried out for each experiment. The coupon surfaces were then rinsed three times with sterilized distilled water to remove the non-adhering bacteria. Thereafter, coupons were immersed in a test tube containing physiological water ( $\mathrm{NaCl}: 9$ g.l-1). Bacterial cells were detached from the coupons surfaces using a sonication bath at $35 \mathrm{kHz}$ (ultrasonic, Germany) for $10 \mathrm{~min}$. CFUs were counted using a serial dilution of the bacterial suspension obtained after sonication. For singlespecies biofilm, nutrient agar was used for bacterial counts. For dual-species biofilm, cetrimide (Biokar diagnostics, France) and Mannitol salt agars were used to count $P$. aeruginosa and $S$. sciuri respectively. Cetrimide and Mannitol salt agars were used as selective media of $P$. aeruginosa and $S$. sciuri, respectively.

\section{Epifluorescence Microscopy Analysis}

Surfaces covered with P. aeruginosa and S. sciuri biofilm were analyzed using an EP (Olympus BX41, Japan) as described previously ${ }^{[5]}$.

\section{Statistical Analyses}

Statistical analyses were performed using STATISTICA version 6. Newman-Keuls test was used to compare the means in $\log _{10}$ $\mathrm{CFU} / \mathrm{cm}^{2}$ (three replicates for each test) and the percentage of each area covered by bacteria (five replicates for each test) ( $p$ value $<0.05$ ).

\section{Results}

\section{P. aeruginosa and S. sciuri Adhesion}

The attachment of S. sciuri and P. aeruginosa to the studied surfaces was examined using PCM and EP (Table 1, Figure 3). S. sciuri showed its capacity to adhere to Rosa Porrino and Gris Pinhel granites and stainless steel 304 and 316 surfaces with 6.50, 6.09, 7.52, and $7.55 \log _{10} \mathrm{CFU} / \mathrm{cm}^{2}$, respectively. P. aeruginosa achieved values of 5.32 (Rosa Porrino), 4.8 (Gris Pinhel), 5.16 (stainless steel 304), and 4.79 (stainless steel 316 ) $\log _{10} \mathrm{CFU} / \mathrm{cm}^{2}$. S. sciuri cells were more adhered to different supports, with a remarkable number on the stainless steel surfaces, whereas no significant difference was noticed in $P$. aeruginosa cells attached to four supports.

The EP analysis (Table 1) showed that S. sciuri covered a greater area on all supports than P. aeruginosa. Stainless steel 304 presented the highest area of bacterial cell coverage, followed by Gris Pinhel granite, which presented $34.98 \%$ and $33.10 \%$ of their areas covered by $S$. sciuri and P. aeruginosa, respectively, whereas stainless steel 316 presented the lowest area covered by $P$. aeruginosa and granite Rosa Porrino represents the lowest area covered by $S$. sciuri. Furthermore, EP observations (Figure 3) showed that $P$. aeruginosa more readily covered the surface of the Rosa Porrino granite, whereas $S$. sciuri cells were more closely affiliated to stainless steel 316 .

\section{Single-species Biofilm Formation}

The results of the $P$. aeruginosa biofilm formation on studied surfaces are presented in Table 2 and Figure 4. Data show that this bacterium adheres and forms a biofilm on Rosa and Gris granites and stainless steel 304 and 316 by reaching 7.69, 7.07, 6.77, 6.77, and $7.61 \log _{10} \mathrm{CFU} / \mathrm{cm}^{2}$, respectively (Table 2). The highest surface coverage of $P$. aeruginosa was on Gris Pinhel with a percentage of $57.66 \%$, whereas the lowest surface coverage was on stainless steel 316 . The statistical analysis of the PCM (Table 2) showed that no significant difference was observed between Rosa Porrino granite and stainless steel 316,

Table 1. Number of Staphylococcus sciuri and Pseudomonas aeruginosa viable cells that adhered after $\mathbf{3}$ of incubation to granite and stainless steel with an area covered by the same bacterial cells

\begin{tabular}{|c|c|c|c|c|}
\hline \multirow[t]{2}{*}{ Surfaces } & \multicolumn{2}{|c|}{$\begin{array}{l}\text { The number of bacterial cells adhered to surfaces } \\
\left(\log _{10} \mathrm{CFU} / \mathrm{cm}^{2}\right)\end{array}$} & \multicolumn{2}{|c|}{ Area covered by bacterial cells ( $\%)$} \\
\hline & S. sciuri & $P$. aeruginosa & S. sciuri & P. aeruginosa \\
\hline Granite Rosa Porrino & $(6.5 \pm 0.06)^{b}$ & $(5.32 \pm 0.35)^{a}$ & $(25.04 \pm 4.81)^{\mathrm{b}}$ & $(21.55 \pm 16.11)^{\mathrm{ab}}$ \\
\hline Granite Gris Pinhel & $(6.09 \pm 0.43)^{b}$ & $(4.80 \pm 0.58)^{\mathrm{a}}$ & $(34.98 \pm 8.91)^{\mathrm{ab}}$ & $(33.10 \pm 9.52)^{\mathrm{ab}}$ \\
\hline Stainless steel 316 & $(7.52 \pm 0.22)^{\mathrm{a}}$ & $(4.79 \pm 1.02)^{\mathrm{a}}$ & $(34.23 \pm 10.70)^{a b}$ & $(16.85 \pm 4.86)^{b}$ \\
\hline Stainless steel 304 & $(7.55 \pm 0.05)^{\mathrm{a}}$ & $(5.16 \pm 0.81)^{\mathrm{a}}$ & $(42.29 \pm 8.08)^{\mathrm{a}}$ & $(45.50 \pm 13.46)^{\mathrm{a}}$ \\
\hline
\end{tabular}




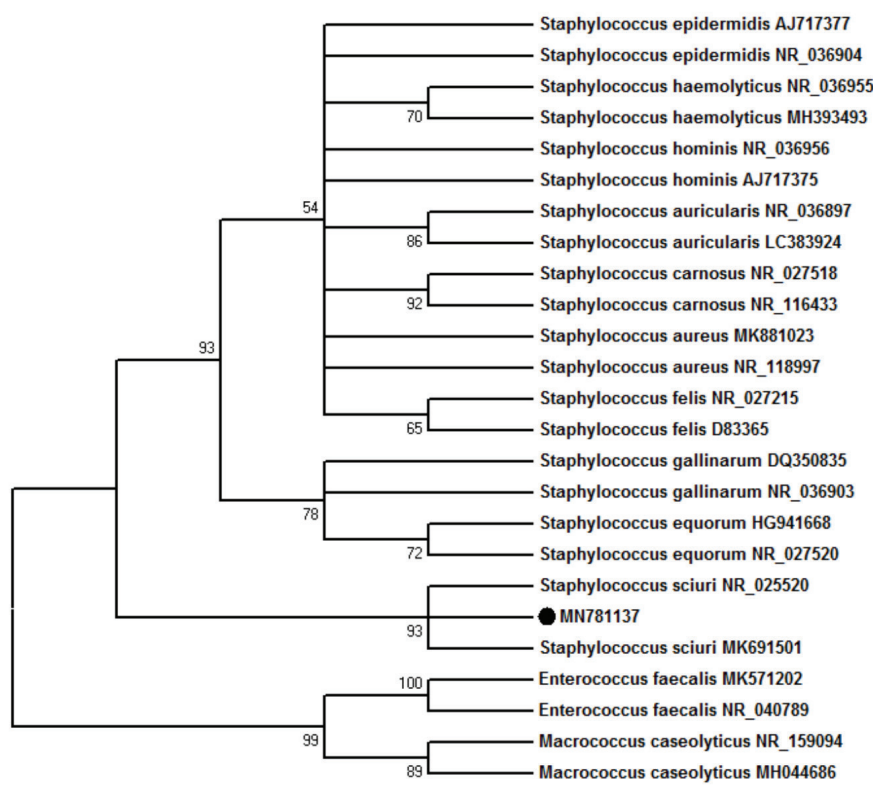

Figure 1. Phylogenetic relationships of Staphylococcus sp. based on 165 partial sequences of the rDNA using the neighbor-joining method. The percentage of replicate trees in which the associated taxa clustered together in the bootstrap test (1,000 replicates) is shown next to the branches. The evolutionary distances were computed using the Kimura two-parameter model and are in the units of the number of base substitutions per site. The rate variation among sites was modeled with a gamma distribution (shape parameter $=1$ ). The analysis involved 25 nucleotide sequences

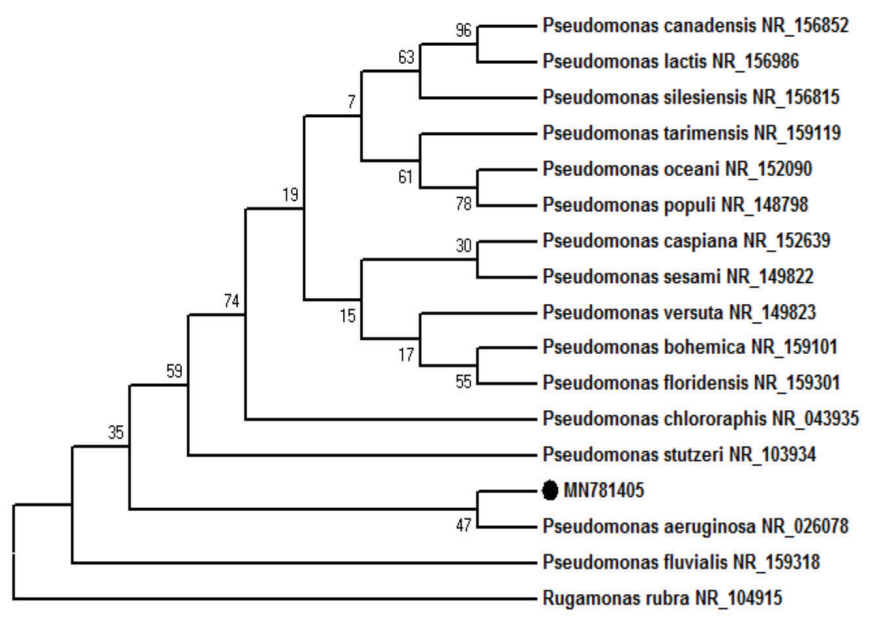

Figure 2. Phylogenetic relationships of Pseudomonas sp. based on 165 partial sequences of the rDNA using the neighbor-joining method. The percentage of replicate trees in which the associated taxa clustered together in the bootstrap test $(1,000$ replicates $)$ is shown next to the branches. The evolutionary distances were computed using the Kimura two-parameter model and are in the units of the number of base substitutions per site. The rate variation among sites was modeled with a gamma distribution (shape parameter $=1$ ). The analysis involved 17 nucleotide sequences

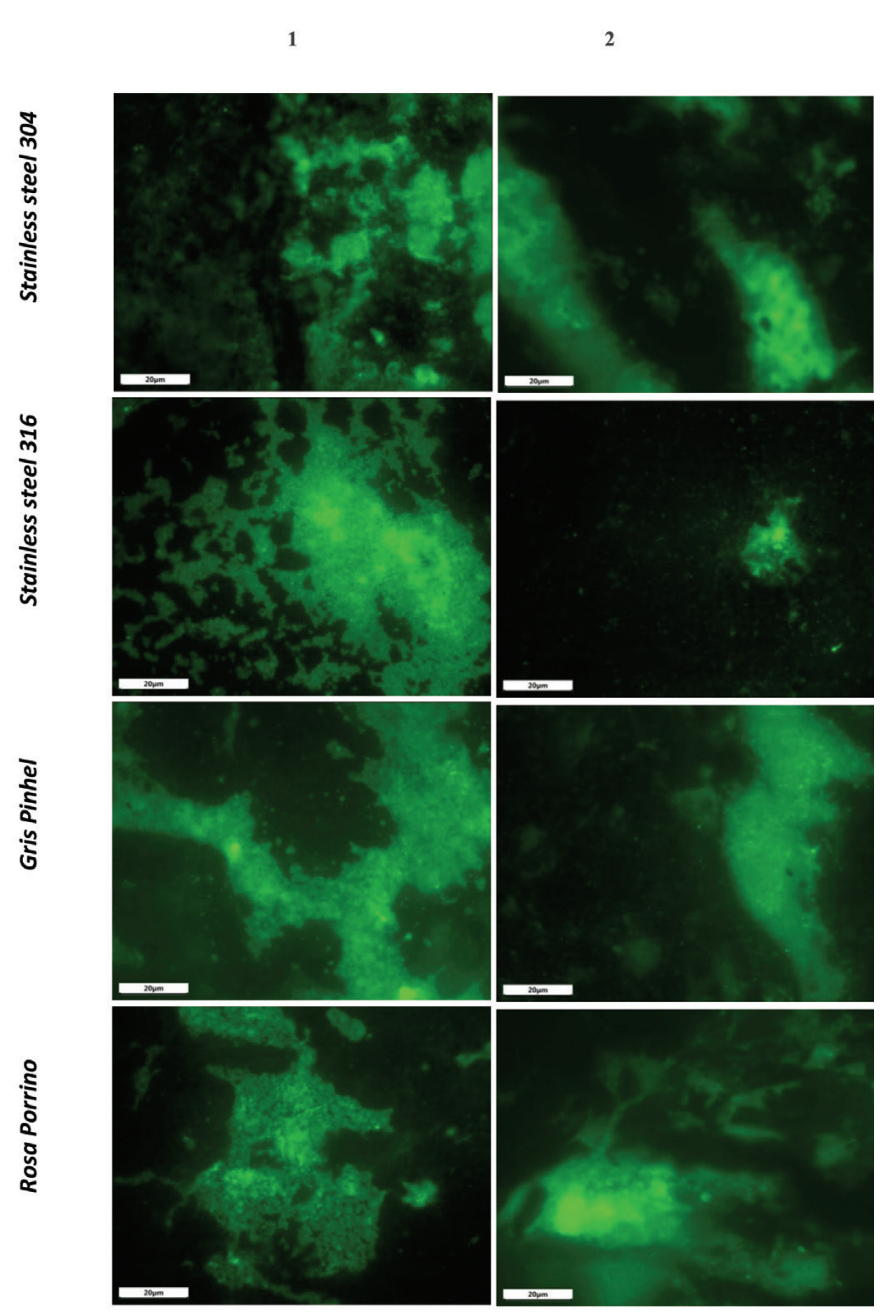

Figure 3. Epifluorescence microscopy observations of S. sciuri [1] and $P$. aeruginosa [2] adhered to stainless steel and granite after $3 \mathrm{~h}$

bar $=20 \mu \mathrm{m}$

which was similar to Gris granite and stainless steel 304 . A significant difference was noticed between the surfaces of the two granites, two stainless steel, granite Rosa and stainless steel 304, and granite Gris and stainless steel 316 .

The results of EP analysis showed a significant difference between granite Rosa and stainless steel 304. Additionally, S. sciuri showed its high capacity to form a biofilm on the four supports compared with P. aeruginosa, reaching 8.21 (Gris), 7.5 (Rosa), 7.83 (stainless steel 316), and $7.82 \log _{10} \mathrm{CFU} / \mathrm{cm}^{2}$ (stainless steel 304), respectively. No significant difference was observed in the number of biofilm cells $\left(\log _{10} \mathrm{CFU} / \mathrm{cm}^{2}\right)$ which had adhered to the two granites and two stainless steel, whereas significance was noted between stainless steel and granite. The highest cell numbers adhered to granite Gris, although fewer adhered to granite Rosa. The results presented in Table 2 relate 
to the area covered by $S$. sciuri cells, of which granite Gris showed the highest percentage (61.63\%) and stainless steel 316 the lowest (34.79\%). The EP images (Figure 4) illustrate that the biofilm cells of $P$. aeruginosa and $S$. sciuri covered greater areas of the stainless steel surface.
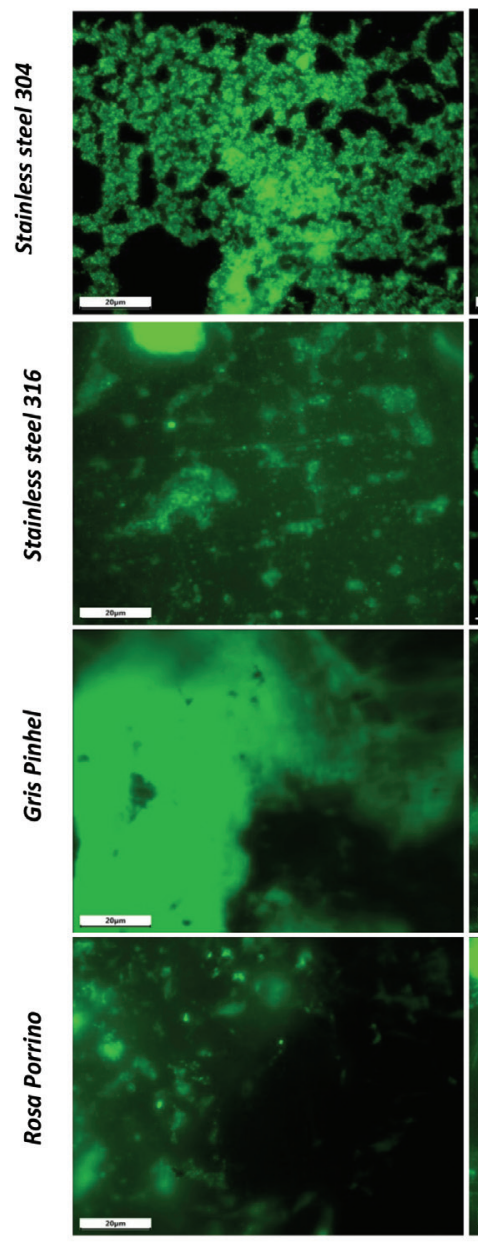
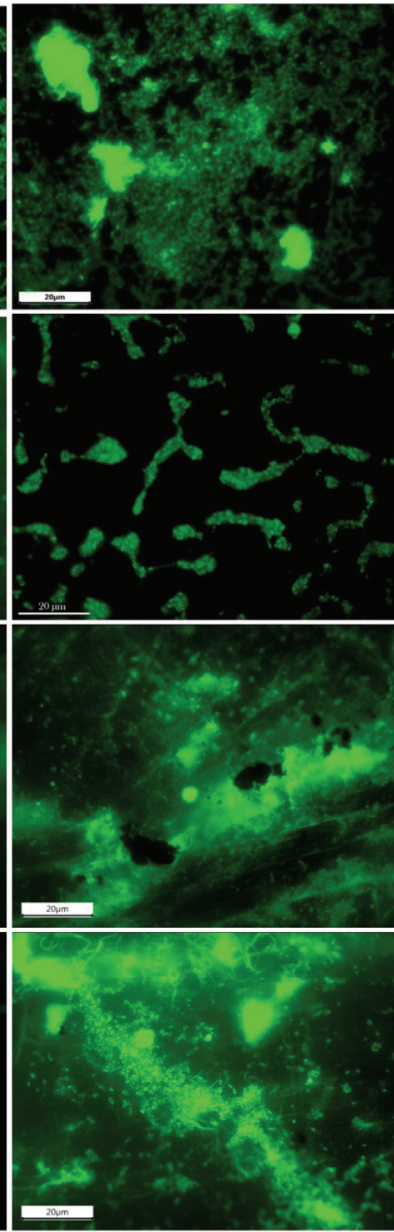

Figure 4. Epifluorescence microscopy observations of S. sciuri [1] and $P$. aeruginosa [2] biofilms formed on the stainless steel and granite surfaces after $24 \mathrm{~h}$

bar $=20 \mu \mathrm{m}$

\section{Dual-species Biofilm Formation}

The dual-species biofilm formation results are shown in Figures 5-7. The number of $S$. sciuri cells, which adhered to different supports, was higher than that of $P$. aeruginosa. No significant differences were noted in the number of $S$. sciuri cells, which adhered to all supports in dual-species culture (Figure 5). Contrastingly, P. aeruginosa adhered more to two stainless steel and granite Gris Pinhel, although with no significant difference. A significant difference was shown between those supports and granite Rosa Porrino, which presented a lower number of $P$. aeruginosa biofilm cells (Figure 5). Contrastingly, the EP results illustrated in Figure 7 demonstrated that granite Rosa and stainless steel 304 contained more dual-species biofilm cells (green fluorescent), whereas granite Gris and stainless steel 316 presented a lower area occupied by P. aeruginosa and S. sciuri biofilms. Results given in Figure 6 showed that granite Rosa and stainless steel 304 presented the largest area covered with dualspecies biofilm where no significant difference was noticed. Moreover, no significant difference $(p<0.005)$ was reported between stainless steel 316 and granite Gris and these supports presented a lower area covered with dual-species biofilm cells (Figure 6).

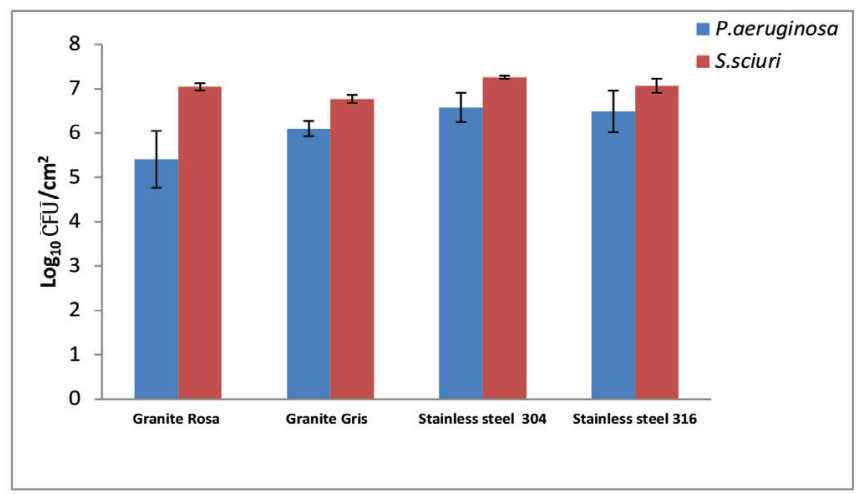

Figure 5. Number of dual-species biofilm cells of $P$. aeruginosa and $S$. sciuri adhered to stainless steel and granite

Table 2. Number of Staphylococcus sciuri and Pseudomonas aeruginosa biofilm cells adhered to granite and stainless steel with an area covered by the same bacterial cells

\begin{tabular}{lllll}
\hline \multirow{2}{*}{ Surfaces } & \multicolumn{2}{l}{$\begin{array}{l}\text { The number of biofilm cells adhered to surfaces } \\
\left(\mathbf{L o g}_{10} \text { CFU/cm }^{2}\right)\end{array}$} & \multicolumn{2}{l}{ Area covered by biofilm cells (\%) } \\
\cline { 2 - 5 } & S. sciuri & P. aeruginosa & S. sciuri & P. aeruginosa \\
\hline Granite Rosa Porrino & $(7.53 \pm 0.13)^{\mathrm{c}}$ & $(7.69 \pm 0.14)^{\mathrm{a}}$ & $(37.32 \pm 8.16)^{\mathrm{a}}$ & $(36.56 \pm 12.78)^{\mathrm{ab}}$ \\
\hline Granite Gris Pinhel & $(8.23 \pm 0.18)^{\mathrm{a}}$ & $(7.07 \pm 0.12)^{\mathrm{b}}$ & $(61.63 \pm 28.13)^{\mathrm{a}}$ & $(57.66 \pm 15.30)^{\mathrm{a}}$ \\
\hline Stainless steel 316 & $(7.82 \pm 0.13)^{\mathrm{bc}}$ & $(7.61 \pm 0.19)^{\mathrm{a}}$ & $(34.79 \pm 3.83)^{\mathrm{a}}$ & $(6.80 \pm 2.93)^{\mathrm{c}}$ \\
\hline Stainless steel 304 & $(7.83 \pm 0.12)^{\mathrm{b}}$ & $(6.77 \pm 0.18)^{\mathrm{b}}$ & $(41.55 \pm 11.01)^{\mathrm{a}}$ & $(48.57 \pm 14.73)^{\mathrm{ab}}$ \\
\hline
\end{tabular}

CFU: Colony-forming units.

ab: Significant difference: when the same latter (example a,a) was given it means that there is no significant difference, whereas when the different letters were given, it means that there is a significant difference (example a, b). 


\section{Discussion}

The adhesion tests to two stainless steels and two granites were carried out. The differences in the number of bacterial cells that adhered to different surfaces were remarked (Table 1 and Figure 3). Differences observed between substrata may not be explained by their roughness; for example, the surface of granite Gris Pinhel is rougher than that of granite Rosa Porrino ${ }^{[5]}$, and Azelmad et al. ${ }^{[8]}$ reported that stainless steel 316 is rougher than stainless steel 304 . Thus, the number of bacterial cells adhering to surfaces does not always increase with an increase in surface roughness. Similarly, hydrophobic and hydrophilic interactions do not explain the differences. Moreover, more cells of $P$. aeruginosa with a hydrophilic character ( $\triangle$ Giwi $=-52.90 \mathrm{~mJ} \mathrm{~m}^{-2}$ ) adhered to the surface of Rosa Porrino with the opposite character

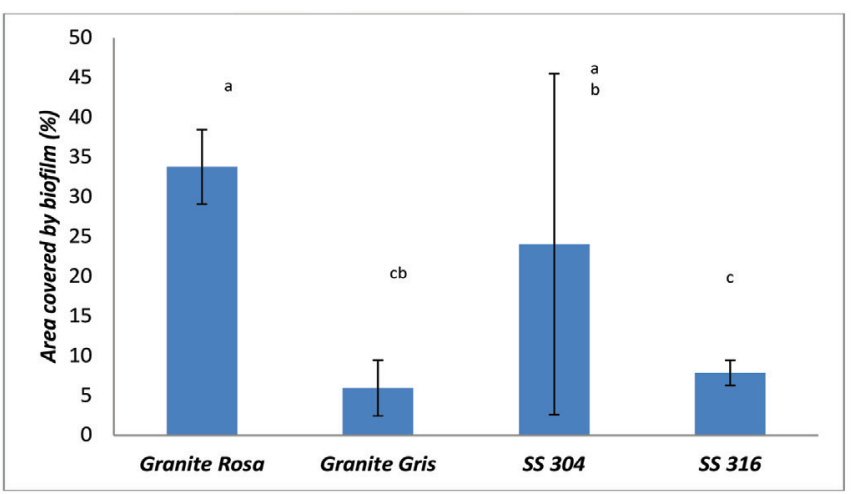

Figure 6. Area covered by S. sciuri and P. aeruginosa dual-species biofilms formed on the stainless steel and granit

$a, b$ c: Significant difference: when the same latter (example ${ }^{a, a}$ ) was given it means that there is no significant difference, whereas when the different letters were given, it means that there is a significant difference (example ${ }^{a, b}$ or ${ }^{b, c}$ ).
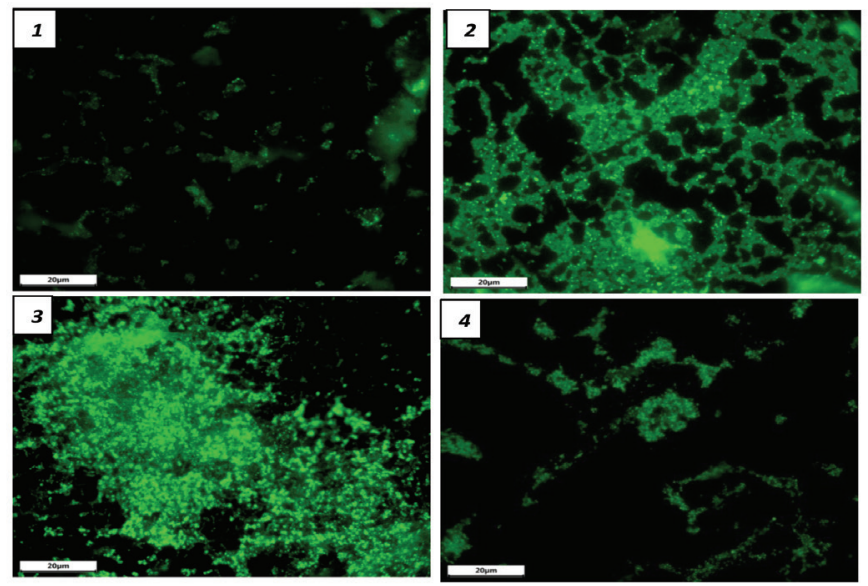

Figure 7. Poly-microbial biofilm of $P$. aeruginosa and S. sciuri formed on stainless steel 304 [1], stainless steel 316 [2], Gris Pinhel [3] granite, and Rosa Porrino granite [4]

bar $=20 \mu \mathrm{m}$
$\left(\Delta \text { Giwi=-63.47 } \mathrm{mJ} \mathrm{m}^{-2}\right)^{[5]}$. Furthermore, S. sciuri was hydrophobic (result not published), although it adhered to stainless steel surfaces with a hydrophilic character ${ }^{[15]}$. A greater number of $P$. aeruginosa cells adhered to Rosa Porrino because this bacterium has a high electron donor character $\left(=9.1 \pm 0.85 \mathrm{~mJ} \mathrm{~m}^{-2}\right)$, and the surface of Rosa Porrino possesses a weak acceptor electron character $\left(=1.600 .06 \mathrm{~mJ} \mathrm{~m}^{-2}\right)$, which allows a good interaction between the two surfaces. Moreover, the high adhesion of S. sciuri (moderate electron donor; $\gamma^{-}=6.9 \pm 1.4 \mathrm{~mJ} \mathrm{~m}^{-2}$ ) was achieved due to the stainless steel surface with a very weak electron acceptor characteristic $\left(\gamma^{+} 0.1 \pm 0.0 \mathrm{~mJ} \mathrm{~m} \mathrm{~m}^{-2}\right)$.

Single-species biofilm results demonstrated that $P$. aeruginosa cells more readily formed a biofilm on Rosa Porrino and Gris Pinhel granites. The EP (Figure 4) showed that more $P$. aeruginosa cells adhered to both granites and stainless steel 304 with a lower amount stuck to stainless steel 316, in accordance with the results of the percentage of area covered by the biofilm cells (Table 2), although they contrast with the PCM results (Table 2). P. aeruginosa is well known for its ability to produce EPSS $^{[16]}$, which have a distinct role in $P$. aeruginosa biofilm development ${ }^{[17]}$. The EP images of a single-species of S. sciuri biofilm demonstrated that this bacterium adheres in bulk to both granites and stainless steel 304 via the matrix of EPS, whereas stainless steel 316 presents a lower number of bacterial cells (Figure 4). The results indicated that $S$. sciuri cells adhered more to the mentioned surfaces compared with $P$. aeruginosa (Table 2). Differences in the number of biofilm cells adhering to the substrata might be due to the increase of the number of bacterial cells initially adhered to the surfaces after the attachment step (3 h), which was higher in S. sciuri compared with $P$. aeruginosa (Table 1 and Figure 3 ).

P. aeruginosa and S. sciuri dual-species biofilm formation results illustrated the strong ability possessed by the two bacteria in forming dual-species biofilm on different substrata (two granites and two stainless steels). P. aeruginosa has previously shown its dominance in dual-species biofilm in the presence of Candida albicans and Candida tropicalis ${ }^{[18]}$. The PCM and EP analysis results revealed that $S$. sciuri adhered to a greater extent on different substrata in the presence of $P$. aeruginosa, which might be due to $S$. sciuri being competitive in biofilm formation than $P$. aeruginosa. Leriche and Carpentier ${ }^{[19]}$ reported that the competition for nutrients associated with the antiadhesive properties of $S$. sciuri biofilms grown in diluted Tryptic Soy Broth with Yeast Extract explains the low levels in the total population of L. monocytogenes and lack of increase in its biofilm population. They also reported that no antimicrobial substances were detected in the supernatant fluids of S. sciuri cultures obtained in the three tested media. The obtained results indicated that the surface type and bacterium strain affect bacterial adhesion and consequently single-species and dual-species biofilm formation. The latter is similar to the author's other findings ${ }^{[20]}$. Conversely, Da Silva Meira et al. ${ }^{[21]}$ 
suggested that the type of surface and incubation temperature were not associated with adherence of their tested isolates of Staphylococcus aureus.

The limitation of this study is the lack of evaluation of the role of $S$. sciuri in the inibition of biofilm and of the determination of substances secreted by S. sciuri having an antibiofilm effect.

\section{Conclusion}

The adhesion and biofilm formation tests indicated that S. sciuri has a greater ability to adhere to both stainless steel and granite than P. aeruginosa. However, S. sciuri was dominant in adhesion and biofilm formation in dual-species biofilms. Therefore, $S$. sciuri has a capacity to affect $P$. aeruginosa adhesion. Furthermore, bacterial strain and surface type influence bacterial adhesion in both single- and dual-biofilm formation. Additional experiments with alternative surfaces and strains are warranted to confirm this finding.

\section{Acknowledgement}

The authors would like to thank Dr. James N. Furze for English correction and style improvement.

\section{Ethics}

Ethics Committee Approval: The study were approved by the Commission Consultative de Bioéthiques Faculté des Sciences Agadir Bioethics Consultative Commission Faculty of Sciences Agadir (ref no: FCR-BS-11/2021-0001, date: 26.11.2021).

Informed Consent: Not applicable.

Peer-review: Externally peer-reviewed.

\section{Authorship Contributions}

Concept: K.A., F.H., R.M., H.L., Design: K.A., F.H., Data Collection or Processing: K.A., J.A.O., A.L., M.Z., A.S., Analysis or Interpretation: K.A., F.H., Literature Search: K.A., Writing: K.A.

Conflict of Interest: No conflict of interest was declared by the authors.

Financial Disclosure: The authors declared that this study received no financial support.

\section{References}

1. Coimbra DG, Almeida $A$, Jorge Jr BO, da Silva $L A F$, Pimentel BJ, Gitaí DLG, Moreira LS, Silva-Filho EA, de Andrade TG. Wound infection by multiresistant Staphylococcus sciuri identified by molecular methods. New Microbiol. 2011;34:425-7.

2. Ahoyo TA, Yehouenou Pazou E, Baba-Moussa L, Attolou Gbohou A, Boco M, Dramane KL, Aminou T. Staphylococcus sciuri outbreak at tertiary hospital in Benin. J Med Microb Diagn. 2013;2:126.

3. Divya S, Thinesh T, Kiran GS, Hassan S, Selvin J. Emergence of a multi host biofilm forming opportunistic pathogen Staphylococcus sciuri D26 in coral Favites abdita. Microb Pathog. 2018;120:204-12.
4. Garza-González E, Morfin-Otero R, Martínez-Vázquez MA, GonzalezDiaz E, González-Santiago 0, Rodriguez-Noriega E. Microbiological and molecular characterization of human clinical isolates of Staphylococcus cohnii, Staphylococcus hominis, and Staphylococcus sciuri. Scand J Infect Dis. 2011;43:930-6.

5. Amzil K, Hamadi F, Latrache H, Mimouni R, Abou Oualid H, Azelmad K, Saidi A, Elboulani A, Mabrouki M. Pseudomonas aeruginosa biofilm removal from two kinds of granite commonly found in catering kitchen. Int J Microbiol. 2020;2020:4313908.

6. Flemming $\mathrm{H}-\mathrm{C}$, Wingender J. The biofilm matrix. Nat Rev Microbiol. 2010;8:623-33.

7. Bridier $A$, Briandet $R$, Thomas $V$, Dubois-Brissonnet F. Resistance of bacterial biofilms to disinfectants: a review. Biofouling. 2011;27:1017-32.

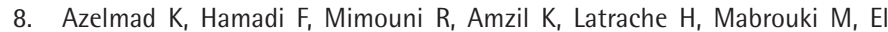
Boulani A. Adhesion of Staphylococcus aureus and Staphylococcus xylosus to materials commonly found in catering and domestic kitchens. Food Control. 2017;73:156-63.

9. Abdallah $M$, Chataigne $G$, Ferreira-Theret P, Benoliel C, Drider D, Dhulster P, Chihib NE. Effect of growth temperature, surface type and incubation time on the resistance of Staphylococcus aureus biofilms to disinfectants. Appl Microbiol Biotechnol. 2014;98:2597-607.

10. Klindworth A, Pruesse E, Schweer T, Peplies J, Quast C, Horn M, Glöckner F0. Evaluation of general $16 \mathrm{~S}$ ribosomal RNA gene PCR primers for classical and next-generation sequencing-based diversity studies. Nucleic Acids Res. 2013;41:e1. doi: 10.1093/nar/gks808.

11. Madden T. The BLAST sequence analysis tool. In: The NCBI Handbook. Bethesda (MD): National Center for Biotechnology Information (US); 2013.

12. Kumar S, Stecher G, Tamura K. MEGA7: molecular evolutionary genetics analysis version 7.0 for bigger datasets. Mol Biol Evol. 2016;33:1870-4.

13. Akbas MY, Cag S. Use of organic acids for prevention and removal of Bacillus subtilis biofilms on food contact surfaces. Food Sci Technol Int. 2016;22:587-97.

14. Hamadi $F$, Latrache $H$, Asserne $F$, Elabed $S$, Zahir $H$, Saad IK, Hanine $H$, Bengourram J. Quantitative adhesion of Staphylococcus aureus on stainless steel coated with milk. Food Nutr Sci. 2013;4:299-304.

15. Amzil $K$, Hamadi F, Mimouni R, Latrache H, Azelmad K, Najih Y, Mabrouki M. Evaluation of sodium hypochlorite efficiency on the elimination of Pseudomonas aeruginosa biofilm using two methods. Russ Open Med J. 2019;8:1-7.

16. Wei Q, Ma LZ. Biofilm matrix and its regulation in Pseudomonas aeruginosa. Int J Mol Sci. 2013;14:20983-5.

17. Yang L, Hu Y, Liu Y, Zhang J, Ulstrup J, Molin S. Distinct roles of extracellular polymeric substances in Pseudomonas aeruginosa biofilm development. Environ Microbiol. 2011;13:1705-17.

18. Bandara H, Yau JYY, Watt RM, Jin U, Samaranayake LP. Pseudomonas aeruginosa inhibits in vitro Candida biofilm development. BMC Microbiol. 2010;10:125.

19. Leriche V, Carpentier B. Limitation of adhesion and growth of Listeria monocytogenes on stainless steel surfaces by Staphylococcus sciuri biofilms. J Appl Microbiol. 2000;88:594-605.

20. Dhowlaghar N, Abeysundara PDA, Nannapaneni R, Schilling MW, Chang $\mathrm{S}$, Cheng $\mathrm{W}-\mathrm{H}$, Sharma CS. Growth and biofilm formation by Listeria monocytogenes in catfish mucus extract on four food contact surfaces at 22 and $10 \mathrm{C}$ and their reduction by commercial disinfectants. J Food Prot. 2018;81:59-67.

21. da Silva Meira QG, de Medeiros Barbosa I, Athayde AJAA, de Siqueira-Júnior $J P$, de Souza EL. Influence of temperature and surface kind on biofilm formation by Staphylococcus aureus from food-contact surfaces and sensitivity to sanitizers. Food Control. 2012;25:469-75. 